\title{
Urgences
}

\section{Récit d'Yves}

\section{Christiane Asselin}

Numéro 15, octobre 1986

Épigraphiques

URI : https://id.erudit.org/iderudit/025311ar

DOI : https://doi.org/10.7202/025311ar

Aller au sommaire du numéro

Éditeur(s)

Urgences

ISSN

0226-9554 (imprimé)

1927-3924 (numérique)

Découvrir la revue

Citer ce document

Asselin, C. (1986). Récit d'Yves. Urgences, (15), 45-45.

https://doi.org/10.7202/025311ar

Ce document est protégé par la loi sur le droit d'auteur. L'utilisation des services d'Érudit (y compris la reproduction) est assujettie à sa politique d'utilisation que vous pouvez consulter en ligne.

https://apropos.erudit.org/fr/usagers/politique-dutilisation/
Cet article est diffusé et préservé par Érudit.

Érudit est un consortium interuniversitaire sans but lucratif composé de l'Université de Montréal, l'Université Laval et l'Université du Québec à Montréal. Il a pour mission la promotion et la valorisation de la recherche. https://www.erudit.org/fr/ 


\section{Christiane Asselin RÉCIT D'YVES}

Que faut-il pour provoquer le rire? demande Machiavel. Des balourdises, des épigrammes, ou des paroles d'amour.

Francis Jacques: Dialogiques

Bien sûr, il l'inviterait chez lui après leur sixième verre. Elle ne dirait pas non, appesantie peut-être par la fumée des cigarettes et le son trop aigu de la disco, immobile depuis six mois dans le coin du bar. Ils prendraient chacun leur auto pour se rejoindre, coin Vimy et Charest, au troisième, première porte à gauche près de l'ascenseur.

Bien sûr, elle arriverait quelques secondes en retard, il l'attendrait. Et c'est là, sous la lumière crue du couloir, qu'ils se verraient vraiment. Elle ne le trouverait pas d'aussi bon goût qu'elle l'avait imaginé. Et lui, il serait surpris de ce visage moins juvénile qu'il ne l'avait espéré. Mais la déception étant chose commune alors ils l'oublieraient bien vite et, nonchalamment, comme s'ils l'avaient toujours fait ensemble, ils entreraient dans l'appartement. Un bachelor, bien sûr, juste assez grand pour y loger (parfois) deux paires de chaussures, pas de la même pointure. Il lui indiquerait la place libre sur la moquette, grise comme eux, et calmement irait chercher deux autres verres.

Un album de photo, délibérément laissé sur la table, servirait de prétexte à un discours futile.

- "Ça c'est moi, au collège. Ici c'est moi, en scout".

Elle rirait, sans avoir regardé vraiment, et ils se tairaient, surpris de n'avoir plus rien à se dire, déjà. Lui, il espérait (une fois de plus) le geste maladroit qui ferait se frôler leurs deux corps. Mais il ne bougerait pas, bien sûr. Il ne bougerait pas... sauf ce geste machinal de la main gauche sur son poignet droit. Et elle suivrait inévitablement le geste du regard, jusqu'à la cicatrice, longue et nette comme une ligne de tramway, du pouce à l'auriculaire.

Elle se lèverait alors, écoeurée, étourdie et quitterait la pièce en ayant l'air de ne pas se précipiter. Lui, il la regarderait en pensant: "Elles font toutes ça", et ressortirait l'ustensile du tiroir, pour la dernière fois, bien sûr. 